\title{
Do Redistricting Commissions Avoid Partisan Gerrymanders?
}

\author{
Robin E. Besta \\ Steve B. Lem ${ }^{b}$ \\ Daniel B. Maglebyc \\ Michael D. McDonald ${ }^{\mathrm{d}}$
}

\begin{abstract}
As attempts to combat partisan gerrymandering transition from proposals before the Supreme Court to state-based districting commissions, it is time to ask this question. How well did the commissions used in the 2010 round of redistricting for states with three of more congressional districts perform in avoiding partisan gerrymanders of congressional districts? We answer that question with applications to each of the three independent commissions (AZ, CA, and WA) and four other commission forms (IA, NJ, NY, and VA) in place for post-2010. We take as the neutrality criterion the idea that a commission would produce a district plan that comports with a partisan outcome that could be expected from a set of approximately 10,000 computer generated plans adhering to minimalist constraints of contiguity, compactness, and equal populations. Our results indicate three of seven commissions produced suspect results that redounded to the benefit of one party or the other: pro-Democrat in Arizona; pro-Republican in New Jersey and Virginia.
\end{abstract}

a Associate Professor of Political Science, rbest@binghamton.edu

b Associate Professor of Political Science, lem@kutztown.edu

c Associate Professor of Political Science, dmagleby@binghamton.edu

d Professor of Political Science, mdmcd@binghamton.edu 
The Supreme Court June 2019 decision, holding "partisan gerrymandering claims present political questions beyond the reach of the federal courts" (Rucho v. Common Cause 2019, slip opinion at 30), makes it likely that attempts to curtail partisan gerrymandering will rest on the effectiveness of redistricting commissions. While other possibilities exist, ${ }^{1}$ commissions are the most frequently promoted solutions among reformers. Moreover, the people in various states appear to agree with the reformers. Since 2015, citizen initiatives in Colorado, Michigan, Missouri, Ohio, and Utah adopted commissions.

Our question is how well do redistricting commissions work in avoiding partisan gerrymanders. Iowa's advisory commission has long been praised for its evenhandedness. Otherwise, however, preliminary evidence points in two directions. Some studies have found that commissions tend to outperform state legislatures when it comes to the competitiveness, compactness, and partisan bias (McDonald 2004; Litton 2012; Edwards et al.2017; Lindgren and Southwell 2013). Jamie Carson and Michael Crespin, whose analysis covers the 1990 and 2000 rounds of redistricting find commissions created more competitive plans than those created by legislatures (Carson and Crespin 2004), and Laura Royden and Michael Li report the use of commissions, post-2010, produced less biased plans than circumstances where a legislature had control, especially with one-party in sole control (Royden and Li 2017). Alex McKenna and his colleagues report that comparisons of the degree of asymmetry (partisan bias) before versus after 2011 show commission plans added less bias than plans drawn in states when one party was in sole control of the process (McKenna et al. 2019; see also McGann et al. 2016).

On the other side of the ledger are those who reach less optimistic conclusions about commissions (Cottrill 2012; Miller and Grofman 2013; Kousseser et al. 2018). For instance, we know that Republicans in Arizona challenged the partisan fairness of its independent commission's plan, which the Supreme Court held, while perhaps suspect,

\footnotetext{
${ }^{1}$ It is possible that for congressional districts Congress could step in under its Article I, section 4 powers, but 220 years of history, where its only meaningful attempt to set a standard was a requirement to use single-member districts (5 Stat.491 [1842] and 2 USC § 29c [1967]), suggests its intervention is highly unlikely. It's also possible that challenges in state courts, as in Pennsylvania and Florida post-2010, will be a sometime-solution (see Wang et al. 2018).
} 
was not intentionally biased. We also know from Jowei Chen and David Cottrell's analysis of all states' congressional districting plans that California's independent commission produced, more so than any other state, bonus seats for Democrats compared to expectations from computer generated neutral districting. And then there is the essentially ignored advisory commission plan that preceded Virginia's legislature taking over the process or redrawing the State's congressional districts. The result was an unconstitutional racial gerrymander (Page v. Virginia State Board of Elections 2015)_with a decidedly pro-Republican bias (Hebert and Lang 2015). In short, commissions probably do a good job relative to having partisan politicians in control, especially partisans of just one stripe, but other evidence leaves one to wonder whether they do a good job by other standards.

In the analyses that follow we assess whether commissions produce district maps that are biased in favor of one party over another. Unlike previous studies that compare maps produced by commissions to those produced by partisan legislatures, we also evaluate commission maps with respect to how well they comport with an outcome that could be expected from a set of approximately 10,000 computer generated plans adhering to minimalist constraints of contiguity, compactness, and equal populations. This avoids the problems inherent in comparing states that may differ in ways other than how their maps are produced. We evaluate whether congressional district maps produced in the 2010 round of redistricting resulted in gerrymanders of partisan exclusion and entrenchment. Our results indicate three of seven commissions produced suspect results that redounded to the benefit of one party or the other: pro- Democrat in Arizona; proRepublican in New Jersey and Virginia.

\section{Commission Forms and Procedures ${ }^{2}$}

Thirteen states provide for commissions to choose a plan or to advise its legislature on selection of congressional and state legislative districts. ${ }^{3}$ Commissions take four forms,

\footnotetext{
2 This section draws on information from on Justin Levitt's “all about redistricting" and Ballopedia websites.

3 Ohio uses an advisory commission for state legislative but not for congressional districts.
} 
Table 1: independent, advisory, politician, and backup. Four states have independent commissions, meaning their commission chooses the lines. California's independent commission members are chosen in a complex sequence, which, in form at least, has minimal input from incumbent politicians. The other three independent commission states-viz., Arizona, Idaho, and Washington-invite bipartisan member selection by sitting politicians. Five states use advisory commissions. Each is akin to legislative leaders putting together a bipartisan conference committee of some active and some not currently active (perhaps never active) politicians. Two states, Hawaii and New Jersey, use political commissions, which similar to advisory commissions, are akin to bipartisan conference committees, but in these two states all but the last selected member is likely to be a currently active political actor. Two states provide for backup commissions whose activation depends on failure of the legislature to adopt a plan. Connecticut's backup commission membership is similar to most states' advisory commissions. Indiana's commission, which has a 30 day period to act, has members with substantial knowledge of the plan or plans the legislature considered.

[Table 1 about here]

The legal charges given to commissions, reflected in Table 2, take as given the federal constitutional requirement of equal populations. They also uniformly specify the often referenced 'good government' criteria of contiguous and compact districts that, so far as practicable, do not breach town, city, or county boundaries. With near equal frequency, commissions are told to pay attention to preservation of communities of interest, either in those words or by reference to historic features. Five states expressly forbid using information on incumbent (or, more generally, candidate) residences-viz., Arizona, California, Iowa, Virginia, and New Jersey. Washington, Rhode Island, and Hawaii expressly call for fairness to groups/parties, while Iowa presumes to do so by ruling out its commission's reliance on political data.

[Table 2 about here]

The district boundary and shape guidelines are forthright constraints on mapmakers, but in most states, not including New York and Rhode Island or, if needed, 
Indiana, commission membership composition is supposed to do much of the heavy lifting for creating a process devoid of self-serving partisan intentions. Still, it is useful to keep in mind a few points about the decision making process, see Table 3. Advisory commissions are just that, advisory; the legislature, subject to gubernatorial veto, retains final decision making authority. Independent commissions, except for California's, operate by majority rule. So, as Peter Miller and Bernard Grofman emphasize, "The first and most obvious point (but still often neglected) is that there are no nonpartisan commissions ...; ... commissions are bipartisan ..." (Miller and Grofman 2013, 644-5).

[Table 3 about here]

The extent of a nonpartisan element is to have one or more nonpartisan members selected by the partisan members (Arizona, Washington, Iowa, New York, Virginia, Hawaii, New Jersey, and Connecticut). Is that enough? Maybe, however, a potential problem is that the sets of equal numbers of partisan members will each promote a degree of partisan advantage in the districting plan favorable to their party, leaving the nonpartisan member(s) to choose between them. One way around this is to require a supermajority vote, effectively requiring cross-party endorsement of a plan, but only California employs such a decision rule. Taken altogether, then, a reasonable expectation is to see commissions as operating in ways similar to a divided government, with one side gaining some sort of upper hand, perhaps by all but forcing a nonpartisan tie-breaker to choose one or the other party's desired plan or perhaps by devising a bipartisan plan so that each party has predictable predominance in its "own" set of districts. Perhaps, however, all the doubts we reference are too cynical, and commissions operated with the sort of nonpartisan fairness the proponents of commissions have in mind. As we've said, our purpose is to check the evidence to see which possibility comes closer to describing the outcomes.

\section{Identifying Gerrymanders}

We seek an application of a metric consistent with the aspirations of partisan fairness congruent with American political traditions. Those traditions have spoken in a 
similar voice since the U.S. Congress first mandated the use of single-member districts for congressional elections. In the 1842 Apportionment Act debate over whether Congress should outlaw the use of at-large voting in House elections, Representation Thomas Arnold (Whig of Tennessee) made this point: "the majority should govern but the minority should be heard" (quoted in Quitt 2008, 638). Nearly a century and a half later, in Davis v. Bandemer $(1986,125)$, Justice White writing for a Court majority made the same point. A preference "for a level of parity between votes and representation sufficient to ensure that significant minority voices are heard, and that majorities are not consigned to minority status, is hardly an illegitimate extrapolation from our general majoritarian ethic and the objective of fair and adequate representation recognized in Reynolds v. Sims" (Davis v. Bandemer 1986, 125).

Gerrymanders, either through delineational manipulations (line-drawing) or choices of institutional arrangements (e.g., at-large voting), potentially create two harms: (1) silencing minority voices, exclusionary gerrymanders, or (2) entrenching one party in majority status almost regardless of their vote support, entrenchment gerrymanders. Each form of potential for harm can be detected through observation of one or another rudimentary statistical indicator from the two-party vote percentage distribution. If one or the other indicator is present, the next step is to check whether the potential for harm produced actual harm that, in fairness, is to be avoided.

The statistical indicator for an exclusionary gerrymander is an abnormally small standard deviation of the vote distribution. ${ }^{4}$ The small standard deviation signals an

4 In a formula the standard deviation is

$$
\sqrt{\sum_{i=1}^{n} \frac{\left(x_{i}-\bar{x}\right)^{2}}{n-1}}
$$

where $x$ is the value of interest for observation $i, \quad \bar{x}$ the average value of interest among all observations, $n$ is the total number of observations. To carry out this calculation, you begin by taking the square of the difference between the value of interest, $x$, for the first observation and the average value of interest, $\bar{x}$, for all observations, and divide that number by the total number of observations minus one, $n-1$. You then repeat this process for every observation, 1 to $n$. The standard deviation is the square root of the sum of this calculation for every observation. In practice, this calculation is simple for a statistical software package. 
homogenization of the two-party vote percentages among districts, similar to what is achieved by using at-large voting where the partisan votes for candidates all tend to split in similar percentages. As applied to delineational gerrymandering the tactic that achieves homogenization is though cracking the minority party vote percentage in as many districts as practicable-i.e., dispersing the votes of minority party voters among numerous districts so that the majority party maximizes the number of districts in which it holds a vote majority. As for entrenchment gerrymanders, the statistical indicator is the skew in the two-party vote percentage distribution. This could be recorded in its full-fledged formulation for calculating skew (McDonald and Engstrom 1989) or its simpler medianminus-mean calculation (McDonald and Best 2015). ${ }^{5}$ The delineational tactic for entrenchment is packing-concentrating large numbers of one party's supporters into a few districts so that the other party can win a large number of districts by reasonably small (but safe) margins.

These statistics are necessary indicators of whether manipulations have been employed, but standing alone they do not indicate whether gerrymandering harm has been imposed. To check for harm they need to be considered along with other indicators that, taken in conjunction, form the proper set of necessary and sufficient conditions, each being necessary and the totality being sufficient to indicate a harmful gerrymander has been wrought.

The relevant questions to ask of commission plans are these.

\section{Exclusionary gerrymanders:}

1. Are voting patterns predictably partisan?

2. Is the standard deviation of the two-party vote percentage distribution smaller than expected due to residential patterns?

3. Are minority party opportunities to win a district minimal?

\footnotetext{
5 See Snedecor and Cochran (1967) for the precise formula for calculating skew. See, e.g., Blalock (1979, 66-7) for a discussion of using the median and mean as a rule of thumb for indicating skewness.

The median is the midpoint score of a set of numbers arranged in order from low to high; the mean is simply the average score. Importantly, as it relates to redistricting partisan politics, having control over the
} 
4. Do the facts of the House elections show minimal inclusion (when, as here, the evaluation takes place post-hoc)?

\section{Entrenchment gerrymanders:}

1. Are voting patterns predictably partisan?

2. Does the median versus mean district percentage difference show a gerrymandering bias running persistently against one set of partisan voters?

3. Does the gerrymandering bias go beyond expected median-mean due to residential patterns?

4. Does the bias violate majority rule under reasonably competitive electoral circumstances, without compensation from turnout bias?

5. Do the facts of the House elections show a similar gerrymandering bias with the disadvantaged party persistently holding a minority of seats in a delegation (when, as here, the evaluation takes place post-hoc)?

A first necessary condition for gerrymandering of either sort, exclusionary or entrenchment, is predictable partisan voting patterns. Absent such predictability there can be no way to say whether a precinct, town, or county can be relied on to vote in support of one party or the other. While crucially important, partisan predictability turns out to be just a minor matter in contemporary American politics. ${ }^{6}$

For an exclusionary gerrymander to cause harm-i.e., silencing minority party voices-as we have said, the choice of where to place the district lines homogenizes the two-party vote percentages, indicated by a standard deviation smaller than expected compared to a state's underlying residential patterns. If a minority party's opportunities to carry a district are de minimis but the standard deviation is as large or larger than expected, then something other than gerrymandering is responsible for the exclusion-e.g. perhaps residential patterns, perhaps overwhelming support for the majority party, or perhaps something else. In other words, a relatively small standard deviation is the

\footnotetext{
${ }^{6}$ Daniel Magleby and his colleagues have looked at the correlations between votes in congressional districts for statewide offices in each of the 38 states with three or more congressional districts. They found high levels of partisan predictability everywhere but Oklahoma and West Virginia (Magleby et al. 2017). ${ }^{6}$ Thereafter, deciding whether a state's districts are a gerrymander requires inquiries into multi-layered necessary conditions applied to case specific circumstances.
} 
leading indicator of the choice to crack a minority party's vote; minimal opportunity to elect minority party members is the harm.

Inferring the existence of entrenchment gerrymanders requires reasoning through four matters beyond partisan predictability. Entrenchment is produced by electoral bias, which is what creates the potential for violating majority rule. Electoral bias is a twoelement concept-turnout bias and gerrymandering bias. To wit,

Total electoral bias $=$ Turnout bias + Gerrymandering bias.

Turnout bias is the difference between a party's statewide vote percentage, which weights each voter equally, and the mean district vote percentage, which weights each district equally (Edgeworth 1898, 536-7; Butler 1951; Erikson 1972, 1236; Gudgin and Taylor 1979, 55-9; Grofman et al. 1997, 461-4)-i.e.,

Turnout bias $=$ Mean district vote\% - Statewide vote\%,

Gerrymandering bias (asymmetry bias due to skew) is the difference between a party's median district vote percentage, which marks the vote percentage received in a district when reaching the threshold of majority control of a delegation, and the mean district vote percentage, which, assuming equal turnout, is the level of vote support for a party (Edgeworth 1898, 534-6; Butler 1951, 330; Erikson 1972, 1237; McDonald and Best 2015; Wang 2016a; 2016b)-i.e.,

Gerrymandering bias = Median district vote\% - Mean district vote\%.

Distinguishing between turnout and gerrymandering bias is but one inferential layer for investigating the possibility of entrenchment gerrymanders. The bias could be natural or chosen, natural in the sense of a median versus mean district percentage difference is attributable to residential patterns or chosen in the sense that a median versus mean difference goes beyond levels attributable to residential patterns. We are interested in choice as a key element in the causal flow, in the sense that the harm would have been reasonably easy to avoid. A median-mean difference is a leading indicator; its persistence above expectations from residential patterns gives rise to the likelihood we are looking at a chosen structural gerrymander. In addition, the choice of a structural gerrymander must show observable harm, not just potential harm. This requires 
observing two additional facts, one ex ante and one ex post. We look ex ante to see whether the disfavored partisans have their majority vote persistently turned into a minority of districts carried using statewide election results, which are all the elections results a commission could have in hand at the time they draw districts. If that does not occur more often than not, then the bias operating against them cannot be deemed to be structural. Finally, given that we are evaluating commissions when the offices of most interest, those elected through the districts, have actually been contested, it is fair to check whether a disfavored party based on statewide results overcame their disfavored position by winning a majority of the actual House contests.

\section{Data}

The data we rely on come from two sources: statewide election returns compiled and disaggregated to voter tabulation districts (VTDs) by Stephen Wolf at Daily Kos (Wolf n.d.) and shapefiles provided by the U.S. Census Bureau.7 Since U.S. elections at all levels are administered by county or local governments, collecting statewide data is often quite challenging. Daily Kos publishes statewide election results by congressional and legislative district built from estimates at the level of VTDs. Wolf uses county-level returns to assign votes to VTDs according to votes cast in the VTD in the 2008 presidential election and the proportion of the county's population living in a VTD. The disaggregation of Democratic votes to VTDs can be characterized by the following equation.

$$
d_{i}^{t}=\delta_{i} D^{t},
$$

where $d_{i}^{t}$ is the estimated number of votes cast for a Democratic candidate in VTD $i$ in election $t, \delta_{i}$ is the proportion of a county's votes cast in VTD $i$ for the Barack Obama in 2008, and $D^{t}$ is the county-level count of Democratic votes for election $t$.

We have tested the accuracy of Wolf's data in Wisconsin, North Carolina, and Florida where we have state-provided official tallies of VTD-level votes. Correlations of

7 VTDs roughly correspond to state designated voting precincts; however, the correspondence to actual voting precincts is not precise. In practice, states re-precinct more frequently than they redistrict. States share their precinct boundaries with the Census Bureau once every ten years, so the VTDs we use to develop our neutral maps are almost certainly out of date by the 2012 and 2014 elections, requiring us to rely on estimated vote totals by VTD. On the other hand, the Census Bureau does ensure that the population reported for VTDs is accurate. 
the Daily Kos numbers and official vote totals were high across all races covered by the data, range from 0.87 to 0.97 .

The Census Bureau is charged with collecting maps of each state's VTDs before each census, and it releases this information as shapefiles. We use these VTD shapefiles to generate 10,000 alternative congressional maps for each state using a graph partitioning process proposed by Daniel Magleby and Daniel Mosesson (Magleby and Mosesson 2018). Each map has the requisite number of contiguous districts with a population variance of plus or minus 1 percent. The process itself is blind to partisan considerations; the computer algorithm considers only population and contiguity of VTDs. After the maps have been generated, we merge VTD voting data from Daily Kos to calculate candidate performance in these alternative congressional districts in each statewide election.

\section{Evaluations}

Figures 1 and 2 offer overviews of the relationships between the homogenization (Figure 1) and electoral bias (Figure 2) in two-party vote percentages in the 34 states we can evaluate for avoiding partisan gerrymanders. ${ }^{8}$ The seven commission states are displayed with red triangles, and all others (district plans chosen by legislatures or courts). One fact is clear. As a generalization, commissions perform relatively better than states that don't use them.

[Figures 1 and 2 about here]

The line at 45 degrees in Figure 1 represents an observed standard deviation corresponding to an outcome that could be expected from the residential pattern of partisan voters. The closer a state is to that line, the closer a choice to let voters fit, generally, into districts with a partisan disposition that their residential location dictates. Outcomes above the line are choices to disperse partisans more widely than would come from their residences. In meaningful political terms, states above the line have created

\footnotetext{
8 The 16 states not included are (1) 12 that have one or two congressional districts and therefore could not have gerrymandered in violation of democratic principles in the American political tradition (2) two states-Kentucky and Oregon-did not provide data at the voter tabulation district level; and (3) two states-Oklahoma and West Virginia-do not display voting patterns with sufficient partisan predictability to think their districts could be gerrymandered.
} 
districts that generally are less competitive (fewer closer to the state average percentage) than expected from residential patterns. Moreover, if the vote distribution take the normal form, a state with a standard deviation around 13.6 has an expected swing ratio (degree of responsiveness) of 3 , as in the once touted cube "law" (see Gudgin and Taylor 1979, 26); and, as Graham Gudgin and Peter Taylor also report, a standard deviation of 20 has an expected swing ratio of 2 (as prescribed by the efficiency gap-see Stephanopolous and McGhee 2015). Many states appear above the 45 degree line, meaning they are choosing plans that have fewer competitive districts than expected. 9 This includes, to varying but noticeable degrees, three commission states-viz., Arizona, Virginia, and New Jersey. The other four commission states are close to the line-viz., Iowa, Washington, California, and New York.

When it comes to adding electoral bias, the 45 degree line in Figure 2, as in Figure 1 , records how close the bias comes to expectations based on residential patterns. Three commission states are almost precisely in line with expectations-viz., New York, Washington, and Iowa. The other four-California, Arizona, New Jersey, and Virginiaeach introduced bias two to three points away from expectations. In the case of California, it's proper to take notice that no harm was done. That's because, while the expected bias operating against Democrats was reduced, the enacted plan continues to have, on average, a modest degree of anti-Democratic bias. In other words, the California commission chose to reduce, but not eliminate, the residential-related bias operating against Democrats. Arizona, New Jersey, and Virginia, on the other hand, each introduced bias that holds the potential to do gerrymandering harm by turning vote majorities into minority congressional delegations. Arizona's enacted plan has an anti-Republican bias; New Jersey and Virginia's have anti-Democratic biases.

The commentary in the previous three paragraphs tells us this much. Commissions tend to do a relatively good job at avoiding partisan gerrymandering, where the baseline for relative comparisons is states not using commissions. Still, it is too much

\footnotetext{
9 The two states appearing as outliers because they have considerably homogenized the district percentages are Maryland (expected just below 16 and observed just above 11) and Utah (expected just above 12 and observed between 5 and 6).
} 
to say that commissions do a uniformly good job. Three of seven commission statesArizona, New Jersey, and Virginia-enacted plans that packed voters in some districts in ways that both reduce the seat-to-vote responsiveness compared to expectations from residential patterns and introduced bias that has the potential to have their election results violate majority rule. Of course, all these preliminary evaluations are based on observing general tendencies, average values; a closer look at the state-by-state details is required to say whether any of the three actually enacted a partisan gerrymander.

\section{Independent Commissions}

We have seen that, on average, Arizona's commission biased elections in favor of Democrats and dispersed partisan voters in such a way to create less competitive districts than partisan residential patterns would indicate. California reduced but did not eliminate anti-Democratic electoral bias arising from residential patterns, and in doing so did not have any noticeable effect of competitiveness beyond what partisan-associated residential patterns would indicate. Finally, the State of Washington's commission drew a plan that reflected the essential consequences of partisan residential patterns, with respect to dispersion and bias.

The details underlying the general tendencies for these three independent commission states are reported in Table 4. The Arizona Commission's operation post2010 was struck with controversy including the ouster of the Commission's nonpartisan arbiter by the Republican Governor and later reinstatement by the State Supreme Court. At issue was the Commission's adopted map, which to Republicans eyes looked like a hit on Republican prospects in the 2012 elections, and likely elections going forward. Republican displeasure was ultimately resolved by the Supreme Court in favor of the Commission's decisions in a two-case sequence, the first was a challenge to the districting process under the Commission; the second was a challenge to the results (Arizona State Legislature v. Arizona Independent Redistricting Commission 2015; Harris v. Arizona Independent Redistricting Commission 2016). 
The dispute over the actual results in the districts was whether the desire to gain advantage for one political party by intentionally over-populating voting districts to comply with the Voting Rights Act can justify devaluing individual votes in violation of the one-person, one-vote principle. While the question as put did not claim Arizona's enacted plan was a partisan gerrymander of the cracking or packing variety - as contrasted with malapportionment with partisan effects - the question of Democratic partisan advantage was easy to see ("Appellants' basic claim is that deviations in their apportionment plan from absolute equality of population reflect the Commission's political efforts to help the Democratic Party," Harris v. Arizona Independent Redistricting Commission 2016, slip opinion at 5).

[Table 4 about here]

The numbers in Table 4 bear this out. In all ten statewide elections we analyze Arizona Democrats have about a two-point advantage from favorable turnout bias. In addition, while the Republicans could expect to balance that pro-Democratic turnout bias with a pro-Republican asymmetry bias (gerrymander bias) associated with residential patterns, the Commission's plan erased the residential pattern favorableness and went a step further by adding about a point and a half of pro-Democratic favorableness due to asymmetry. On those two scores Republicans were right to claim mistreatment (in addition to the fact that the Commission plan paired two Republican incumbents, and the pairing was despite the addition of one congressional district after the 2010 Census).

The potential for harm to Republicans, and at least in one sense observable harm, can been seen in the facts that in the two closest elections of our ten-Attorney General in 2010 and U.S. Senate in 2012-the Democratic candidates won just over 48 percent of the two-party vote and carried 5 of 9 congressional districts. Nevertheless, the contramajoritarian nature of Arizona's districts did not treat Republicans so harshly as to allow Democrats to entrench themselves in majority status of the State's congressional delegation throughout the decade. Republicans were able to win 5 of 9, a majority, congressional seats in both 2014 and 2016. 
Both the California and Washington commissions operate as one would expect from a process with no partisan tilt one way or the other. As was clear from Figure 1, the observed and expected standard deviations closely match in both states. The observed gerrymandering bias (i.e., asymmetry) leans in both directions, usually with slight favoritism toward Republicans but in a few elections with slight favoritism toward Democrats. In both states there is nothing to see in terms of a tilted playing field one way or another and, from that, no harm that could have been produced through the chosen district plans.

\section{Advisory and Politician Commissions}

As is apparent from the data in Figures 1 and 2, there is not much to say about dubious districting results in Iowa. From the details in Table 5, there is but a mild suggestion that Iowa's districting process created more highly competitive districts than residential patterns alone would suggest. A consequence is that with 55 percent of the vote both parties win all four of the State's congressional districts. Someone might want to argue about whether such strong responsiveness is desirable, but any such argument is not about whether the district plan is more favorable to one party and less favorable to the other.

The most noticeable characteristic for New York is that the role of an advisory commission and subsequent choice, actually made by a court with the assistance of a special master, did little or nothing to reduce the bias associate with the downstateupstate concentrations of Democratic and Republican voters. Here, again, one might want to argue that it would be proper, and surely not objectionable, for the choice of districts lines to reduce the built-in residential bias operating against New York Democrats. Reducing that built-in bias could help to eliminate a contra-majoritarian result where, as in the Comptroller race in 2010, the Democratic candidate wins 52 percent of the vote but carries just 11 of 27 districts. Still, such an argument is asking for a great deal of fine turning to account for an unusual results, inasmuch as most statewide races have 
Democrats winning 55 to 65 percent of the vote and its congressional delegation split about two-to-one in favor of Democrats.

[Table 5 about here]

New Jersey's results in Table 5 bear a similarity to New York's, with several of the statewide races being lopsided Democratic candidate wins. That makes it difficult to reach a firmly stated evaluation. Nevertheless, the district lines show signs that districts have been drawn in ways that typically are less competitive than a partisan blind process would produce. That reading comes from the uniformly larger standard deviations compared to the average in the set of 10,000 computer generated maps. In addition, the lines added gerrymander bias (asymmetry bias) of between 1.7 and 3.7 points operating against Democrats. Some, but not all of that gerrymander bias, is offset by the 1.3 to 2.5 points of favorable turnout bias to Democrats. Even though, as we remarked, the lopsided outcomes make firm statements difficult, it is remarkable that even with 55.5 percent of the vote in the 2013 special election for U.S. Senate, the Democrat carried just 6 or 12 districts-not a full-fledged undermining of majority rule, but a dubious result nonetheless.

The most important point to make about Virginia's advisory commission is that it had little to do with the congressional district plan the State adopted. While the State Legislature had plans before it and advisory commission advice in April 2011, the divided Legislature (State House under Republican control and State Senate under Democratic control), it wasn't until after the November elections, in which the Senate split 20-20 and the Republican Lieutenant Governor could cast a tie-breaking vote, that Virginia settled on a congressional plan. It was, unsurprisingly, the one Republicans preferred, and it was a pro-Republican gerrymander.

Virginia has become a closely competitive state with predictable partisan voting patterns. Despite its competitiveness, Democrats were able to win just three of eleven House races in 2012 and 2014 (and four of eleven after the map was redrawn for the 2016 election). Notable, too, under Virginia's pro-Republican congressional district lines enacted in 2012 and used in 2012 and 2014, Barack Obama won 52 percent of the two- 
party vote and carried just four of eleven districts. His was not the only statewide election in violation of majority rule. Table 5 shows that in seven of the ten elections the Democrat won a two-party vote majority. Five of those times their majority vote percentage was between 50 and 53.2. Nevertheless, the majority preferred Democrat failed to carry a majority of districts in four of those five elections. This occurred as a consequence of 2.7 to 4.0 asymmetry biases operating to the detriment of Democrats (see the median-mean gerrymandering bias numbers in Table 5). The bias is persistent; it occurs in all ten elections we observe. What is more, except in Mark Warner's abnormally lopsided 2008 U.S. Senate victory, less than 1 percent of all the partisan blind plans have asymmetry values (median - mean differences) with magnitudes larger than those observed based on the district lines chosen by the State.

The evidence points strongly and convincingly to the fact that Virginia's 2012-14 congressional districts was a partisan gerrymander. The plan was persistently biased against Democrats in all elections that were anything within earshot of being competitive. Four of five times when a Democrat won a vote majority with percentages between 50 and 54 , the candidate failed to carry a majority of districts. The bias and majority rule failing are certainly not attributable to residential patterns, as ascertainable by comparison to the computer generated 10,000 partisan blind maps. And, finally, in the 2012-14 House elections Democrats won just three House seats, telling us that they did not possess resources necessary to overcome the disadvantage imposed by the district lines.

The short version of the Virginia story is that the State enacted a Republican gerrymander. It wasn't chosen or even suggested by the State's advisory committee, but the existence of the committee did nothing to help ward off the enactment. ${ }^{10}$

\section{Conclusion}

Substantial evidence suggests redistricting commissions do a good job delivering on the charges they have been given-e.g., meeting population equality, drawing

\footnotetext{
${ }^{10}$ In February, 2019, Virginia lawmakers approved a constitutional amendment to create a new bipartisan commission to be used in the 2020 redistricting cycle. To win final approval, the proposal will need to be approved by the Legislature again in 2020 and then go on the November 2020 ballot for voter approval (see, Lau 2019).
} 
contiguous and reasonably compact districts, preserving jurisdictional boundaries, and creating competitive districts. The same cannot be said, at least uniformly, about how well commissions avoid partisan gerrymanders.

Adopting a bipartisan, independent commission with an inclusive decision rule (California) can work to avoid a gerrymander; so, too, does one with a majority decision rule (Washington), but not always (e.g., Arizona). Having an advisory commission can also avoid partisan gerrymanders, as in Iowa. But, the advice has to be heeded not ignored, as in Virginia. And, where the bipartisanship offers little more than to have a nonpartisan choose between competing party desires to promote their partisan interests it is possible that a fait accompli gerrymander will follow, as in New Jersey.

Aside from the glaring problem, apparent in Virginia, that advisory commissions can be ignored, a fundamental problem for any and all commissions is their adoption focuses on form and not substance. Commissions are given no charge, or at most a vague charge, to avoid partisan gerrymanders. The missing meaningful charge likely reflects the same problem the Supreme Court sees for itself, a fatalist resignation that no discernable and manageable standard exists. A starting point is to acknowledge some sort of standard is needed. One that recognizes a minimalist adherence to American political traditions that sizable partisan minorities are to have some voice and that no party is to be able to entrench itself in power regardless of its level of vote support is one possibility. 
Figure 1: Relationship between Observed and Expected Standard Deviation in

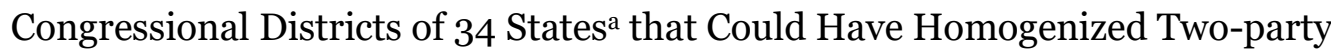
Vote percentages, by whether They Used Redistricting Commissions

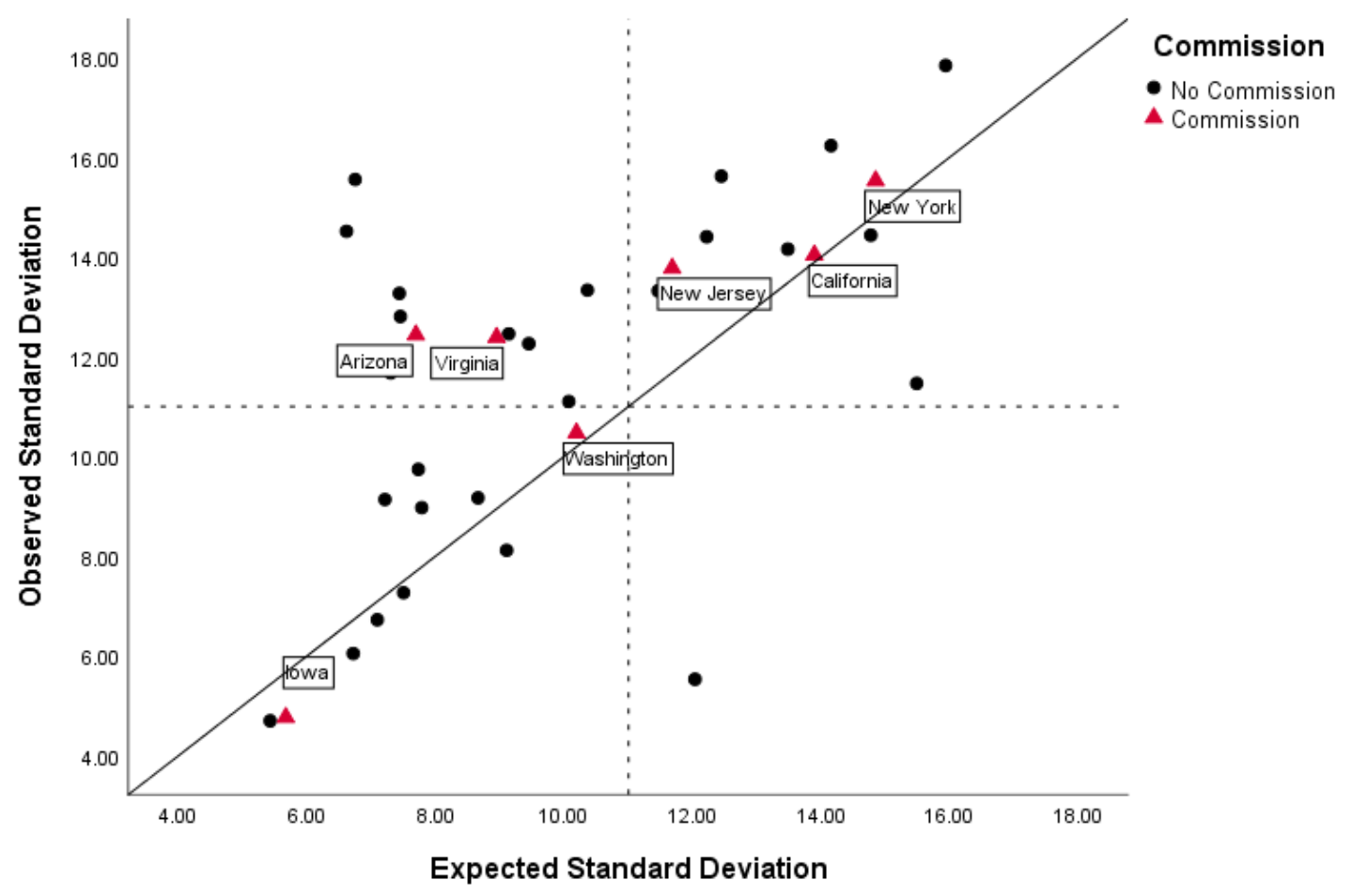

aThe 16 states not included are (1) 12 that have one or two congressional districts and therefore could not have gerrymandered in violation of democratic principles in the American political tradition (2) two statesKentucky and Oregon-did not provide data at the voter tabulation district level; and (3) two statesOklahoma and West Virginia-do not display voting patterns with sufficient partisan predictability to think their districts could be gerrymandered. 
Figure 2: Relationship between Observed and Expected Skew (Median - Mean Difference) in Congressional Districts of 34 States $^{\text {a }}$ that Could Have Biased Electoral Outcomes, by whether They Used Redistricting Commissions

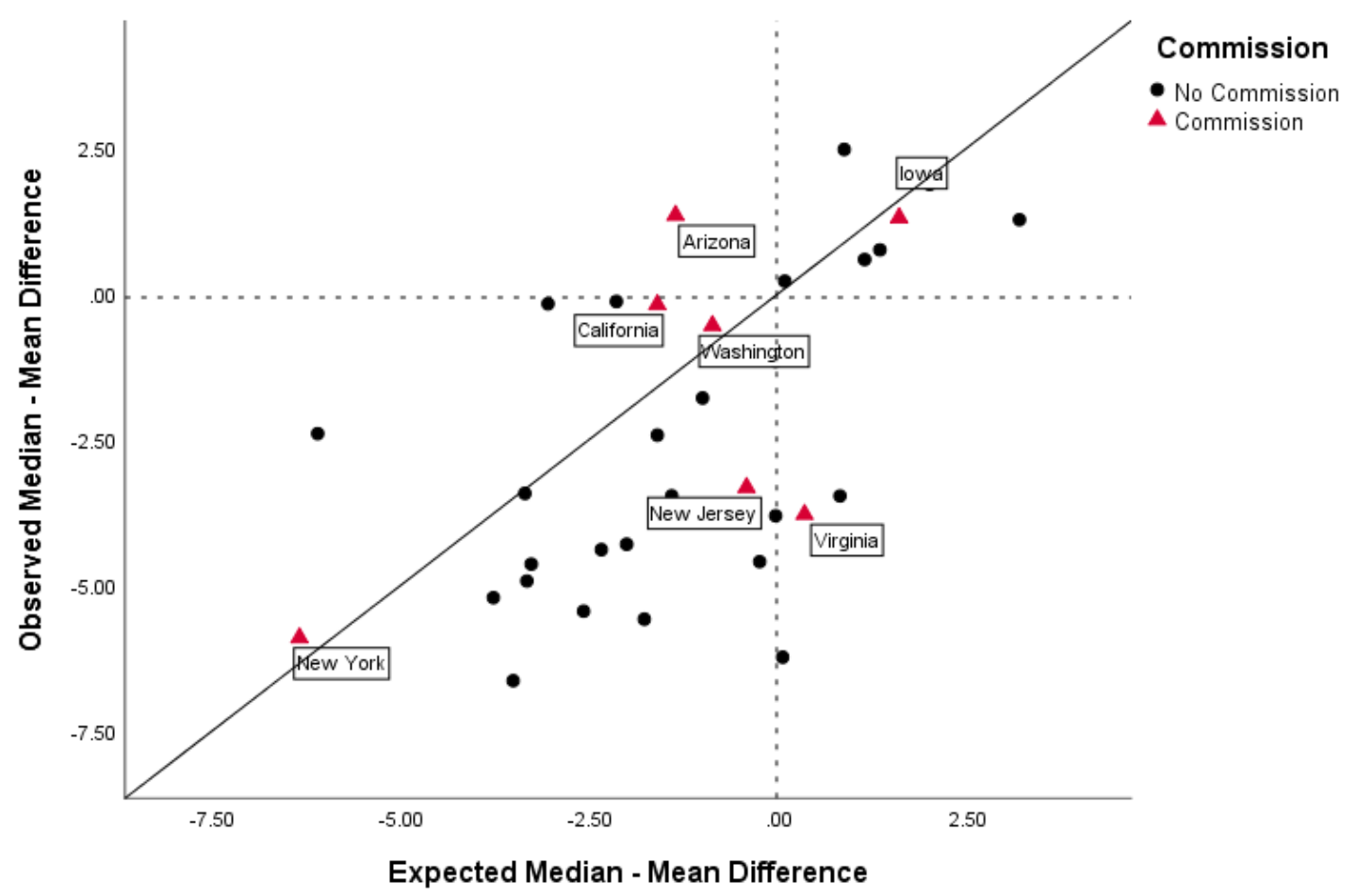

${ }^{a}$ The 16 states not included are (1) 12 that have one or two congressional districts and therefore could not have gerrymandered in violation of democratic principles in the American political tradition (2) two statesKentucky and Oregon - did not provide data at the voter tabulation district level; and (3) two statesOklahoma and West Virginia-do not display voting patterns with sufficient partisan predictability to think their districts could be gerrymandered. 
Table 1: Redistricting Commission Membership Selection

\begin{tabular}{|c|c|}
\hline $\begin{array}{l}\text { Commission } \\
\text { Type }\end{array}$ & Membership \\
\hline \multicolumn{2}{|l|}{ Independent } \\
\hline Arizona & 5 members: not recent politician, 4 political selections $\& 5^{\text {th }}$ by those 4 \\
\hline California & $\begin{array}{l}14 \text { members: not recent politician, pool of } 60 \text { names }(20 \mathrm{R}, 20 \mathrm{D}, 20 \mathrm{Indy}) \text {, political } \\
\text { leaders exclude } 8 \rightarrow 8 \text { selected at random \& those } 8 \text { select } 6\end{array}$ \\
\hline Idaho & 6 members: not current politician, D\&R party leaders selected all 6 \\
\hline Washington & $\begin{array}{l}5 \text { members: not recent politician, } D \& R \text { leaders select } 2 \text { each, and those } 4 \text { select a } \\
\text { nonvoting Chair }\end{array}$ \\
\hline \multicolumn{2}{|l|}{ Advisory } \\
\hline lowa & $\begin{array}{l}\text { Legislative Service Agency (civil servants) guided by } 5 \text { member commission with } 1 \\
\text { each by the Majority and Minority leaders and those } 4 \text { select the } 5^{\text {th }}\end{array}$ \\
\hline Maine & 15 members: 6 each by party leaders, the 12 select 2 and those 2 select the $15^{\text {th }}$ \\
\hline New York & $\begin{array}{l}6 \text { members: } 4 \text { state legislators, } 2 \text { not legislators with } 1 \text { by Senate leaders and } 1 \text { by } \\
\text { Assembly leaders }\end{array}$ \\
\hline Rhode Island & $\begin{array}{l}18 \text { members: } 8 \text { legislators by Majority leaders, } 4 \text { legislators by Minority leaders, } \\
\text { and six not legislators by Majority leaders }\end{array}$ \\
\hline Virginia & 11 members: 5D and 5R by the Governor and those 10 select an independent \\
\hline \multicolumn{2}{|l|}{ Politician } \\
\hline Hawaii & 9 members: Majority and Minority leaders select 4 each, those 8 select $9^{\text {th }}$ \\
\hline New Jersey & $\begin{array}{l}13 \text { members: Majority and Minority leaders each select } 4 \text {, state party chairs } \\
\text { select } 2 \text { each, and those } 12 \text { select a } 13^{\text {th }}\end{array}$ \\
\hline \multicolumn{2}{|r|}{ - } \\
\hline Connecticut & $\begin{array}{l}9 \text { members: Majority and minority leaders in each legislative house select } 2 \text { each, } \\
\text { those } 8 \text { select } 9^{\text {th }}\end{array}$ \\
\hline Indiana & $\begin{array}{l}5 \text { members: speaker of the house, president pro tem of the senate, the chairman } \\
\text { of the house and senate committees on legislative apportionment, and a fifth } \\
\text { member appointed by the governor from the membership of the general } \\
\text { assembly }\end{array}$ \\
\hline \multicolumn{2}{|c|}{${ }^{1}$ Idaho has an Independent Commission but only two House seats. } \\
\hline \multicolumn{2}{|c|}{${ }^{2}$ Maine and Rhode Islands have Advisory Commissions but only two House seats. } \\
\hline \multicolumn{2}{|c|}{${ }^{3}$ Hawaii has a Politician Commission but only two House seats. } \\
\hline
\end{tabular}


Table 2: Charges Given to Redistricting Commissions

\begin{tabular}{|c|c|}
\hline $\begin{array}{l}\text { Commission } \\
\text { Type }\end{array}$ & Charges \\
\hline \multicolumn{2}{|l|}{ Independent } \\
\hline Arizona $^{6}$ & $\begin{array}{l}\text { Contiguous, compact, preserve communities of interest, use visible geographic features } \\
\text { (city, town, county, and undivided census tracts). Competitiveness is secondary. Party } \\
\text { registration and voting records may not be used in the initial phase but later to check if } \\
\text { goals are achieved. Cannot consider candidate homes. }\end{array}$ \\
\hline California & $\begin{array}{l}\text { Contiguous and preserve communities of interest. Compactness is secondary. Cannot } \\
\text { consider candidate homes. }\end{array}$ \\
\hline Idaho & $\begin{array}{l}\text { Contiguous and preserve counties - if a county is split across districts, must be connected } \\
\text { by a state or federal highway. Districts should preserve communities of interest and voting } \\
\text { precincts. }\end{array}$ \\
\hline Washington & $\begin{array}{l}\text { Contiguous, compact, and convenient. Should follow natural, geographic, artificial, or } \\
\text { political subdivision boundaries. Cannot favor or discriminate against any particular party } \\
\text { or group. Should preserve communities of interest. Commission should "provide fair and } \\
\text { effective representation and encourage electoral competition." }\end{array}$ \\
\hline \multicolumn{2}{|r|}{ ( T } \\
\hline lowa & $\begin{array}{l}\text { Contiguous and preserve the boundaries of other political subdivisions. Compact as long } \\
\text { as consistent with higher order principles - regular polygons, length-width, and perimeter } \\
\text { standards. May not use incumbent addresses, previous election results, or demographic } \\
\text { data other than population headcount. }\end{array}$ \\
\hline Maine & Compact and contiguous. Cross fewest political subdivisions as possible. \\
\hline New York & $\begin{array}{l}\text { Contiguous and as compact "as practicable" and take into account the "historic and } \\
\text { traditional significance of counties." }\end{array}$ \\
\hline Rhode Island & $\begin{array}{l}\text { Compact, should reflect natural, historical, geographical, and municipal and other political } \\
\text { lines. Fair representation and equal access to the political process. Attempt to avoid } \\
\text { dividing state Senate districts into congressional districts if it would result in a voting } \\
\text { district of } 100 \text { or fewer voters. }\end{array}$ \\
\hline Virginia & $\begin{array}{l}\text { Contiguous and compact (Constitution); communities of interest - economic, social, } \\
\text { cultural, geographic features, governmental jurisdictions and service delivery areas, } \\
\text { political beliefs, voting trends, and incumbency considerations (commission); protect } \\
\text { political subdivisions, counties, cities, and communities of interest as much as possible } \\
\text { (governor) }\end{array}$ \\
\hline \multicolumn{2}{|r|}{ (c } \\
\hline Hawaii & $\begin{array}{l}\text { Contiguous, compact, and follow permanent and easily recognized features. Should also } \\
\text { preserve communities of interest - defined specifically as socioeconomic. Districts cannot } \\
\text { favor persons or political factions. }\end{array}$ \\
\hline New Jersey & $\begin{array}{l}\text { Contiguous and compact. Municipalities must also be kept intact. Conflicting judicial } \\
\text { precedent on using incumbent residence. }\end{array}$ \\
\hline \multicolumn{2}{|r|}{ - } \\
\hline Connecticut & $\begin{array}{l}\text { Activates if general assembly fails to adopt a plan by Sept. } 15 \text { of year after decennial } \\
\text { census. Boundaries must be consistent with federal constitutional standards. State } \\
\text { Assembly and Senate districts shall be contiguous; assembly districts should not divide } \\
\text { towns. }\end{array}$ \\
\hline Indiana & $\begin{array}{l}\text { Activates if general assembly adjourns without adopting a plan or if the state finds itself } \\
\text { without a valid congressional district law. Constitution requires assembly districts are } \\
\text { contiguous. No guidelines for Congressional lines, although Indiana code provides specific } \\
\text { details for resolution of inconsistent inclusions and geographic slivers in Congressional } \\
\text { districts. }\end{array}$ \\
\hline
\end{tabular}


Table 2: Decision Procedures of Redistricting Commissions

\begin{tabular}{|c|c|}
\hline $\begin{array}{l}\text { Commission } \\
\text { Type }\end{array}$ & Decision Procedures \\
\hline \multicolumn{2}{|l|}{ Independent } \\
\hline Arizona & $\begin{array}{l}\text { Draft map advertised for } 30 \text { days to the public. Both chambers may make } \\
\text { recommendations to the commission during this period. } 3 / 5 \text { commission votes required } \\
\text { for final map. }\end{array}$ \\
\hline California & $\begin{array}{l}\text { Open public meetings around state. } 9 \text { commission votes - } 3 \text { Dems, } 3 \text { Rep, } 3 \text { neither - } \\
\text { required. Final map approved by public referendum. }\end{array}$ \\
\hline Idaho & $\begin{array}{l}\text { Open public meetings around state. } 2 / 3 \text { commission votes required for final map within } \\
90 \text { days after commission is formed. }\end{array}$ \\
\hline Washington & $\begin{array}{l}\text { Open public meetings distributed via interactive webcast. Three voting members of } \\
\text { commission required for final map. If commission fails, state supreme court creates plan. } \\
\text { Legislature may amend proposed plan by } 2 / 3 \text { majority vote in both chambers within } 30 \\
\text { days of submission. }\end{array}$ \\
\hline \multicolumn{2}{|r|}{ 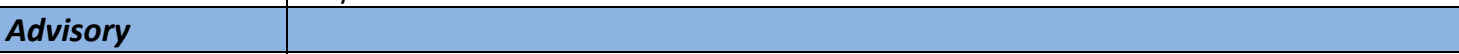 } \\
\hline lowa & $\begin{array}{l}\text { The Legislative Services Agency (LSA) works with commission to advise legislature. Must } \\
\text { publicize plan and data and hold three hearings around state. Plan, data, and public } \\
\text { feedback presented to legislature to be accepted or rejected without modification. If } \\
\text { rejected, second plan presented. If second plan rejected, a third and final set presented, } \\
\text { which may be modified at the legislature's discretion. }\end{array}$ \\
\hline Maine & $\begin{array}{l}\text { Public hearings prior to submission. The legislature shall enact the submitted plan of the } \\
\text { commission or a plan of its own by a } 2 / 3 \text { majority vote by June } 11 \text {. Plan subject to } \\
\text { gubernatorial veto. If no plan is approved by June } 11 \text {, state supreme court shall consider } \\
\text { plans and public briefs to create plan. }\end{array}$ \\
\hline New York & $\begin{array}{l}\text { Legislative task force on demographic research and apportionment, with approval of its } \\
\text { co-chairmen, recommends a plan to the state legislature. Legislature may accept, reject, } \\
\text { or modify plans, which are subject to gubernatorial veto. }\end{array}$ \\
\hline Rhode Island & $\begin{array}{l}\text { Commission sets its own rules of procedure. Must conform to Open Meeting and Access } \\
\text { to Public Records laws. Makes recommendation to state legislature, which approves as a } \\
\text { regular statute that is subject to gubernatorial veto. }\end{array}$ \\
\hline Virginia & $\begin{array}{l}\text { Commission may create own plan or accept one from the public. Submit to both chambers } \\
\text { of the legislature, which may accept, reject, or modify plans. Bill subject to gubernatorial } \\
\text { veto. }\end{array}$ \\
\hline \multicolumn{2}{|l|}{ Politician } \\
\hline Hawaii & $\begin{array}{l}\text { Public hearings around state; at least } 1 \text { on each island. Majority of commission votes } \\
\text { required for final map within } 150 \text { days after commission is formed. }\end{array}$ \\
\hline New Jersey & $\begin{array}{l}\text { Three public hearings around state. Should review maps submitted by citizens if time } \\
\text { allows. Majority commission votes required for final map in open meeting. Otherwise, two } \\
\text { highest voted plans go to state Supreme Court. }\end{array}$ \\
\hline \multicolumn{2}{|l|}{ Backup } \\
\hline Connecticut & $\begin{array}{l}5 / 9 \text { votes for final map by Nov. } 13 \text {. Upon delivery to Secretary of State, it is published and } \\
\text { have the full force of law. If the commission fails to deliver a map by Nov. 13, the state } \\
\text { Supreme Court has jurisdiction and ability to file a map. }\end{array}$ \\
\hline Indiana & $\begin{array}{l}\text { Majority }(3 / 5) \text { votes for final map within } 30 \text { days of assembly adjournment. Upon delivery } \\
\text { to Governor, the plan put into effect by executive order. }\end{array}$ \\
\hline
\end{tabular}


Table 4: Evidence of Skew and Reduced Variation in Two-party Vote Percentages under Independent Redistricting Commissions

\begin{tabular}{|c|c|c|c|c|c|c|c|c|c|c|c|c|}
\hline State & Year & Office & $\begin{array}{c}\text { Total } \\
\text { Vote\% }\end{array}$ & $\begin{array}{l}\text { Mean } \\
\text { District } \\
\text { Vote\% }\end{array}$ & $\begin{array}{l}\text { Median } \\
\text { District } \\
\text { Vote\% }\end{array}$ & $\begin{array}{c}\text { Turnout } \\
\text { Bias }\end{array}$ & $\begin{array}{c}\text { Obs } \\
\text { Gerry- } \\
\text { mander } \\
\text { Bias }\end{array}$ & $\begin{array}{c}\text { Exp } \\
\text { Gerry- } \\
\text { mander } \\
\text { Bias }\end{array}$ & $\begin{array}{l}\text { Obs } \\
\text { Std } \\
\text { Dev }\end{array}$ & $\begin{array}{l}\text { Exp } \\
\text { Std } \\
\text { Dev }\end{array}$ & $\begin{array}{c}\text { Obs } \\
\text { Wins }\end{array}$ & $\begin{array}{l}\text { Exp } \\
\text { Wins }\end{array}$ \\
\hline \multirow[t]{4}{*}{$\mathrm{AZ}$} & 2008 & President & 45.69 & 47.36 & 48.40 & 1.67 & 1.04 & -1.27 & 10.39 & 6.96 & 3 & 2.55 \\
\hline & \multirow[t]{7}{*}{2010} & Atty General & 48.11 & 50.06 & 50.29 & 1.95 & .23 & -1.52 & 11.12 & 7.15 & 5 & 3.47 \\
\hline & & Governor & 43.87 & 46.09 & 46.59 & 2.22 & .50 & -1.47 & 12.88 & 8.42 & 3 & 2.24 \\
\hline & & Mine Insp & 42.87 & 45.11 & 47.19 & 2.25 & 2.07 & -1.55 & 13.02 & 8.22 & 2 & 1.95 \\
\hline \multirow{6}{*}{9 Districts } & & US Senate & 37.06 & 39.13 & 40.49 & 2.08 & 1.36 & -1.35 & 11.97 & 7.65 & 2 & .64 \\
\hline & & Sec of State & 41.79 & 44.00 & 46.66 & 2.21 & 2.65 & -1.09 & 12.86 & 8.16 & 2 & 1.69 \\
\hline & & Supt Ed & 44.67 & 46.82 & 48.66 & 2.15 & 1.85 & -1.15 & 12.21 & 7.67 & 3 & 2.40 \\
\hline & & Treasurer & 44.38 & 46.61 & 49.16 & 2.24 & 2.54 & -1.64 & 12.83 & 8.15 & 2 & 2.49 \\
\hline & \multirow{2}{*}{2012} & President & 45.39 & 47.70 & 48.72 & 2.31 & 1.01 & -1.37 & 13.57 & 7.22 & 3 & 2.56 \\
\hline & & US Senate & 48.41 & 50.69 & 51.46 & 2.28 & .77 & -1.39 & 13.51 & 7.34 & 5 & 3.67 \\
\hline \multirow[t]{5}{*}{$\overline{\mathrm{CA}}$} & 2008 & President & 62.12 & 62.36 & 62.46 & .24 & .10 & -1.40 & 12.91 & 13.03 & 43 & 41.56 \\
\hline & \multirow{8}{*}{2010} & Atty General & 50.39 & 51.11 & 49.37 & .72 & -1.74 & -2.67 & 14.25 & 14.39 & 25 & 24.55 \\
\hline & & Comp & 60.41 & 61.16 & 61.18 & .75 & .01 & -1.26 & 13.49 & 13.35 & 41 & 40.60 \\
\hline & & Governor & 56.72 & 57.50 & 56.51 & .78 & -.98 & -1.85 & 14.01 & 13.87 & 37 & 33.21 \\
\hline & & Ins Comm & 57.36 & 58.32 & 58.80 & .96 & .47 & -1.31 & 14.11 & 13.95 & 36 & 34.61 \\
\hline \multirow[t]{6}{*}{53 Districts } & & LT GOV & 56.25 & 56.37 & 56.40 & .12 & .03 & -1.65 & 13.79 & 14.50 & 34 & 32.11 \\
\hline & & US Senate & 55.30 & 56.16 & 55.81 & .86 & -.36 & -1.73 & 15.73 & 15.17 & 32 & 29.96 \\
\hline & & Sec of State & 58.18 & 59.08 & 58.93 & .89 & -.15 & -1.75 & 14.42 & 14.12 & 38 & 34.93 \\
\hline & & Treasurer & 60.93 & 61.77 & 61.61 & 84 & -.16 & -1.57 & 13.42 & 13.38 & 41 & 39.91 \\
\hline & \multirow{2}{*}{\begin{tabular}{|l|}
2012 \\
\end{tabular}} & President & 61.87 & 62.47 & 62.88 & .60 & .41 & -1.20 & 14.27 & 13.51 & 41 & 40.44 \\
\hline & & US Senate & 62.52 & 63.00 & 63.33 & .48 & .33 & -1.42 & 14.00 & 13.54 & 41 & 41.22 \\
\hline \multirow[t]{9}{*}{ WA } & \multirow[t]{9}{*}{2008} & Atty General & 40.54 & 40.32 & 41.21 & -.22 & .89 & -1.29 & 8.65 & 8.46 & 1 & 1.13 \\
\hline & & Auditor & 63.54 & 62.85 & 62.48 & -.68 & -.37 & .02 & 10.04 & 9.73 & 9 & 9.08 \\
\hline & & Governor & 53.24 & 52.40 & 51.58 & -.84 & -.81 & -.76 & 11.19 & 10.58 & 5 & 6.39 \\
\hline & & Ins Comm & 61.38 & 60.68 & 60.45 & -.71 & -.23 & -.12 & 10.38 & 10.02 & 9 & 8.96 \\
\hline & & Land Comm & 50.55 & 50.03 & 46.75 & -.52 & -3.28 & -2.61 & 10.23 & 10.03 & 3 & 3.18 \\
\hline & & Lt Gov & 60.80 & 60.24 & 59.87 & -.56 & -.37 & -.81 & 8.72 & 8.82 & 9 & 8.23 \\
\hline & & President & 58.75 & 57.85 & 57.78 & -.90 & -.07 & -.76 & 11.62 & 11.14 & 8 & 7.96 \\
\hline & & Sec of State & 41.67 & 41.44 & 39.92 & -.23 & -1.52 & -1.31 & 8.69 & 8.54 & 1 & 1.20 \\
\hline & & Treasurer & 51.08 & 50.65 & 49.77 & -.43 & -.89 & -1.35 & 9.02 & 8.76 & 5 & 4.17 \\
\hline \multirow{12}{*}{10 Districts } & 2010 & US Senate & 52.37 & 51.61 & 50.85 & -.76 & -.76 & -.82 & 11.90 & 11.22 & 5 & 5.80 \\
\hline & \multirow[t]{11}{*}{2012} & Atty Gen & 53.48 & 52.60 & 52.11 & -.88 & -.48 & -.29 & 11.77 & 11.23 & 6 & 5.60 \\
\hline & & Auditor & 52.95 & 52.22 & 51.42 & -.73 & -.81 & -.95 & 11.04 & 10.77 & 5 & 6.17 \\
\hline & & Governor & 51.54 & 50.75 & 49.51 & -.79 & -1.23 & -1.25 & 10.62 & 10.28 & 5 & 4.57 \\
\hline & & Ins Comm & 58.30 & 57.51 & 57.05 & -.79 & -.46 & -.28 & 11.69 & 11.09 & 7 & 7.33 \\
\hline & & Land Comm & 58.74 & 57.92 & 57.36 & -.82 & -.56 & -.82 & 12.05 & 11.33 & 8 & 7.87 \\
\hline & & Lt Gov & 53.68 & 53.30 & 53.60 & -.38 & .30 & -1.12 & 7.03 & 8.59 & 6 & 6.01 \\
\hline & & President & 57.63 & 56.69 & 56.62 & -.94 & -.07 & -.51 & 12.26 & 11.67 & 7 & 7.06 \\
\hline & & US Senate & 60.45 & 59.67 & 59.14 & -.78 & -.53 & -.49 & 10.99 & 10.56 & 8 & 8.00 \\
\hline & & Sec of State & 49.62 & 48.87 & 46.01 & -.76 & -2.86 & -1.40 & 10.60 & 10.61 & 4 & 3.25 \\
\hline & & Treasurer & 58.71 & 57.98 & 57.28 & -.73 & -.70 & -.89 & 10.91 & 10.42 & 8 & 7.99 \\
\hline & & US Senate & 52.85 & 53.05 & 48.85 & .19 & -4.19 & -1.65 & 14.07 & 8.46 & 3 & 4.68 \\
\hline
\end{tabular}

Total vote\%-Democratic candidate percentage of the statewide two-party vote

Mean District Vote\%-Democratic candidate average district percentage of the two-party vote

Median District Vote\%-Democratic candidate median district percentage of the two-party vote.

Turnout Bias-the difference in weight given to Democratic or Republican voters as a consequence of differential turnout rates among districts. Positive values show pro-Democratic turnout advantage; negative values show pro-Republican turnout advantage.

Obs Gerrymander Bias-observed gerrymander bias indicates a vote weight advantage for Democratic or Republican voters as a consequence of the disadvantaged partisans residing in districts relatively more packed with co-partisans.

Exp Gerrymander Bias-expected gerrymander bias based on 10,000 maps drawn by a computer program in a partisan blind manner, where gerrymander bias is defined above.

Obs Std Dev-observed standard deviation of Democratic two-party vote percentage among districts.

Exp Std Dev-expected standard deviation of Democratic two-party vote percentage among districts based on 10,000 maps drawn by a computer program in a partisan blind manner.

Obs Wins-observed number of districts carried (i.e., wins) by the Democratic statewide candidate

Exp Wins - expected number of districts carried (i.e., average number of wins) by the Democratic statewide candidate based on 10,000 maps drawn by a computer program in a partisan blind manner. 
Table 5: Evidence of Skew and Reduced Variation in Two-party Vote Percentage under Advisory and Politician Redistricting Commissions

\begin{tabular}{|c|c|c|c|c|c|c|c|c|c|c|c|c|}
\hline State & Year & Office & $\begin{array}{c}\text { Total } \\
\text { Vote } \%\end{array}$ & $\begin{array}{c}\text { Mean } \\
\text { District } \\
\text { Vote\% }\end{array}$ & $\begin{array}{l}\text { Median } \\
\text { District } \\
\text { Vote\% }\end{array}$ & $\begin{array}{c}\text { Turnout } \\
\text { Bias }\end{array}$ & $\begin{array}{c}\text { Obs } \\
\text { Gerry- } \\
\text { mander } \\
\text { Bias }\end{array}$ & $\begin{array}{c}\text { Exp } \\
\text { Gerry- } \\
\text { mander } \\
\text { Bias }\end{array}$ & $\begin{array}{l}\text { Obs } \\
\text { Std } \\
\text { Dev }\end{array}$ & $\begin{array}{l}\text { Exp } \\
\text { Std } \\
\text { Dev }\end{array}$ & $\begin{array}{c}\text { Obs } \\
\text { Wins }\end{array}$ & $\begin{array}{l}\text { Exp } \\
\text { Wins }\end{array}$ \\
\hline IA & 2008 & \begin{tabular}{|l|} 
President \\
\end{tabular} & 54.85 & 54.81 & 55.49 & -.03 & .67 & 1.39 & 4.59 & 5.48 & 3 & 3.01 \\
\hline & \multirow[t]{6}{*}{2010} & Agri Comm & 37.13 & 37.15 & 38.18 & .02 & 1.02 & .85 & 5.54 & 5.95 & 0 & .00 \\
\hline & & Atty General & 55.56 & 55.55 & 56.09 & -.01 & .54 & 1.86 & 3.78 & 5.22 & 4 & 3.16 \\
\hline \multirow[t]{5}{*}{4 Districts } & & Auditor & 43.52 & 43.51 & 44.72 & .00 & 1.21 & 1.41 & 5.18 & 5.84 & 0 & .14 \\
\hline & & \begin{tabular}{|l|} 
Governor \\
\end{tabular} & 45.00 & 44.99 & 46.39 & -.01 & 1.40 & 1.99 & 4.90 & 6.14 & 0 & .31 \\
\hline & & US Senate & 34.10 & 34.12 & 34.89 & .02 & .77 & 1.11 & 4.76 & 5.49 & 0 & .00 \\
\hline & & \begin{tabular}{|l|} 
Treasurer \\
\end{tabular} & 52.93 & 52.92 & 54.14 & -.01 & 1.22 & 2.13 & 4.24 & 5.19 & 3 & 3.00 \\
\hline & 2012 & \begin{tabular}{|l|} 
President \\
\end{tabular} & 52.96 & 52.89 & 54.40 & -.07 & 1.50 & 1.92 & 5.16 & 6.07 & 3 & 3.00 \\
\hline \multirow[t]{3}{*}{$\mathrm{NJ}$} & \multirow[t]{2}{*}{2008} & \begin{tabular}{|l|} 
President \\
\end{tabular} & 57.86 & 59.17 & 56.47 & 1.31 & -2.70 & -.16 & 12.26 & 10.42 & 8 & 9.35 \\
\hline & & \begin{tabular}{|l} 
US Senate \\
\end{tabular} & 57.18 & 58.86 & 56.66 & 1.68 & -2.21 & -.50 & 12.78 & 10.77 & 9 & 9.29 \\
\hline & 2009 & Governor & 48.08 & 50.40 & 45.83 & 2.32 & -4.57 & -.71 & 14.93 & 13.08 & 5 & 5.39 \\
\hline \multirow[t]{4}{*}{12 Districts } & \multirow{2}{*}{2012} & \begin{tabular}{|l} 
President \\
\end{tabular} & 58.98 & 60.47 & 58.14 & 1.48 & -2.33 & -.25 & 13.89 & 11.36 & 8 & 9.40 \\
\hline & & US Senate & 59.89 & 61.61 & 58.83 & 1.72 & -2.79 & -.13 & 14.24 & 11.84 & 9 & 9.45 \\
\hline & \multirow[t]{2}{*}{2013} & Governor & 38.78 & 41.23 & 36.33 & 2.46 & -4.90 & -1.15 & 13.95 & 11.52 & 2 & 2.03 \\
\hline & & US Senate Sp & 55.51 & 57.45 & 52.81 & 1.94 & -4.64 & -.17 & 14.34 & 12.78 & 6 & 8.40 \\
\hline \multirow[t]{4}{*}{ NY } & 2008 & \begin{tabular}{|l|} 
President \\
\end{tabular} & 63.57 & 65.47 & 59.41 & 1.90 & -6.07 & -6.34 & 15.50 & 15.05 & 24 & 24.77 \\
\hline & \multirow[t]{5}{*}{2010} & Atty General & 56.52 & 60.41 & 53.28 & 3.89 & -7.13 & -7.41 & 17.59 & 16.62 & 16 & 16.66 \\
\hline & & \begin{tabular}{|l} 
Comptroller \\
\end{tabular} & 52.35 & 56.68 & 48.65 & 4.33 & -8.02 & -8.36 & 18.23 & 17.31 & 11 & 12.13 \\
\hline & & Governor & 65.68 & 69.33 & 65.14 & 3.65 & -4.20 & -5.13 & 15.90 & 15.83 & 24 & 24.91 \\
\hline \multirow[t]{4}{*}{27 Districts } & & US Senate & 67.32 & 70.50 & 64.14 & 3.18 & -6.86 & -5.89 & 13.66 & 13.01 & 27 & 27.00 \\
\hline & & US Senate Sp & 64.21 & 67.44 & 60.44 & 3.23 & -6.99 & -6.12 & 14.27 & 13.63 & 27 & 27.00 \\
\hline & \multirow[t]{2}{*}{2012} & \begin{tabular}{|l|} 
President \\
\end{tabular} & 64.27 & 66.33 & 59.86 & 2.06 & -6.47 & -6.80 & 16.62 & 15.59 & 24 & 25.11 \\
\hline & & US Senate & 73.28 & 74.93 & 69.29 & 1.66 & -5.65 & -4.81 & 12.46 & 11.70 & 27 & 27.00 \\
\hline \multirow[t]{5}{*}{ VA } & \multirow[t]{2}{*}{2008} & \begin{tabular}{|l} 
President \\
\end{tabular} & 53.18 & 53.20 & 49.24 & .02 & -3.96 & .21 & 12.03 & 8.38 & 5 & 6.71 \\
\hline & & \begin{tabular}{|l} 
US Senate \\
\end{tabular} & 65.85 & 65.18 & 63.50 & -.67 & 1.68 & -.68 & 7.78 & 4.68 & 11 & 11.00 \\
\hline & \multirow[t]{3}{*}{2009} & Atty General & 42.44 & 43.39 & 38.00 & .96 & -5.39 & -.76 & 12.54 & 9.46 & 3 & 2.94 \\
\hline & & Governor & 41.31 & 42.19 & 37.50 & .88 & -4.69 & -1.20 & 12.31 & 7.86 & 3 & 1.36 \\
\hline & & LtGovernor & 43.44 & 44.37 & 39.70 & .93 & -4.67 & .09 & 12.39 & 8.38 & 3 & 2.09 \\
\hline \multirow[t]{5}{*}{11 Districts } & \multirow[t]{2}{*}{2012} & \begin{tabular}{|l|} 
President \\
\end{tabular} & 51.97 & 52.00 & 49.31 & .04 & -2.70 & 1.02 & 13.25 & 9.57 & 4 & 6.47 \\
\hline & & US Senate & 52.96 & 53.04 & 50.08 & .08 & -2.95 & 1.08 & 12.64 & 9.29 & 6 & 6.71 \\
\hline & \multirow[t]{3}{*}{2013} & Atty General & 50.02 & 50.30 & 46.87 & .27 & -3.42 & .56 & 14.11 & 10.95 & 4 & 5.57 \\
\hline & & \begin{tabular}{|l|} 
Governor \\
\end{tabular} & 51.35 & 51.56 & 48.52 & .21 & -3.05 & 1.40 & 14.25 & 10.92 & 4 & 6.22 \\
\hline & & Lt Gov & 55.31 & 55.54 & 52.21 & .23 & -3.32 & 1.60 & 12.54 & 10.02 & 7 & 7.33 \\
\hline
\end{tabular}

Total vote\%-Democratic candidate percentage of the statewide two-party vote

Mean District Vote\%-Democratic candidate average district percentage of the two-party vote

Median District Vote\%-Democratic candidate median district percentage of the two-party vote.

Turnout Bias-the difference in weight given to Democratic or Republican voters as a consequence of differential turnout rates among districts. Positive values show pro-Democratic turnout advantage; negative values show pro-Republican turnout advantage.

Obs Gerrymander Bias-observed gerrymander bias indicates a vote weight advantage for Democratic or Republican voters as a consequence of the disadvantaged partisans residing in districts relatively more packed with co-partisans.

Exp Gerrymander Bias-expected gerrymander bias based on 10,000 maps drawn by a computer program in a partisan blind manner, where gerrymander bias is defined above.

Obs Std Dev-observed standard deviation of Democratic two-party vote percentage among districts.

Exp Std Dev-expected standard deviation of Democratic two-party vote percentage among districts based on 10,00o maps drawn by a computer program in a partisan blind manner.

Obs Wins-observed number of districts carried (i.e., wins) by the Democratic statewide candidate

Exp Wins - expected number of districts carried (i.e., average number of wins) by the Democratic statewide candidate based on 10,000 maps drawn by a computer program in a partisan blind manner. 


\section{References}

Arizona State Legislature v. Arizona Independent Redistricting Commission. 2015. 576 U.S.

Best, Robin E., Shawn Donahue, Jonathan Krasno, Daniel Magleby, and Michael D. McDonald. 2017. "Considering the Prospects for Establishing a Packing Gerrymandering Standard.” Election Law Journal 17: 1-20.

Blalock, Hubert M., Jr. 1979. Social Statistics (revised $2^{\text {nd }}$ ed.). New York: McGrawHill.

Butler, David E. 1951. “Appendix.” In H. G. Nichols, The British General Elections of 1950. London: Oxford University Press, 306-33.

Carson, Jamie L., and Michael H. Crespin. 2004. "The Effect of State Redistricting Methods on Electoral Competition in United States House of Representatives Races." State Politics and Policy Quarterly 4(4): 455-469.

Chen, Jowei and Jonathan Rodden. 2013. "Unintentional Gerrymandering: Political Geography and Electoral Bias in Legislatures.” Quarterly Journal of Political Science 8: 239-69.

Chen, Jowei and David Cottrell. 2016. "Evaluation Partisan Gains from Congressional Gerrymandering: Using Computer Simulations to Estimate the Effect of Gerrymandering in the U.S. House.” Electoral Studies 44:329-40.

Cottrill, James B. 2012. "The Effects of Non-Legislative Approaches to Redistricting on Competition in Congressional Elections." Northeastern Political Science Association 44(11): 32-50.

Davis v. Bandemer. 1986. 478 U.S. 109.

Edgeworth, Francis Y. 1898. "Miscellaneous Applications of the Calculus of 
Edwards, Barry, Michael Crespin, Ryan D. Williamson, and Maxwell Palmer. 2017. "Institutional Control of Redistricting and the Geography of Representation." The Journal of Politics 79(2): 722-726.

Erikson, Robert S. 1972. "Malapportionment, Gerrymandering, and Party Fortunes in Congressional Elections.” American Political Science Review 66: 1234-45.

Grofman, Bernard, William Koetzle, and Thomas Brunell. 1997. “An Integrated Perspective on the Three Potential Sources of Partisan Bias: Malapportionment, Turnout Differences, and the Geographical Distribution of Party Vote Shares." Electoral Studies 16: 457-70.

Gudgin, Graham and Peter J. Taylor. 1979. Seat, Votes, and the Spatial Organisation of Elections. London, UK: Pion.

Harris v. Arizona Independent Redistricting Commission. 2016. 578 U.S.

Hebert, J. Gerald and Danielle Lang. 2015. "Memorandum of Amici Curiae Common Cause and Virginia New Majority Regarding Proposed Remedial Plans.” U.S. District Court for the Eastern District of Virginia (3:13-cv-678).

Keena, Alex, Michael Latner' Charles Anthony Smith, and Anthony J. McGann. 2019. "Here's How to fix Partisan Gerrymander, Now that the Supreme Court Has Kicked it Back to the States." Washinton Post (Monkey Cage), July 2.

Kousser, Thad, Justin Phillips, and Boris Shor. 2018. "Reform and Representation: A New Method Applied to Recent Electoral Changes." Political Science Research and Methods 6(4): 809-827.

Lau, Tim. 2019. “A Bipartisan Win for Redistricting Reform in Virginia.” At https://www.brennancenter.org/blog/bipartisan-win-redistricting-reform-virginia

Lindgren, Eric, and Priscilla Southwell. 2013. "The Effect of Redistricting Commissions on Electoral Competitiveness in U.S. House Elections, 2002-2010. Journal of Politics and Law 6(2): 13-18. 
Litton, Noah. 2012. "The Road to Better Redistricting: Empirical Analysis and State-Based Reforms to Counter Partisan Gerrymandering. Ohio State Law Review 73(4):839881.

Magleby, Daniel B. and Daniel B. Mosesson. 2018. "Neutral Redistricting Using a MultiLevel Weighted Graph Partitioning Algorithm.” Political Analysis 26: 147-67.

Magleby, Daniel, Shawn Donahue, Michael D. McDonald, Robin E. Best, and Jonathan Krasno. 2017. “Observing Congressional District Gerrymanders, Post-2010.” Paper presented at the ElP Workshop on Protecting Electoral Security and Voting Rights: The 2016 US Election in Comparative Perspective. San Francisco, CA.

McDonald, Michael D. and Richard L. Engstrom. 1989. "Detecting Gerrymanders." In Bernard Grofman (ed.) Toward Fair and Effective Representation: Political Gerrymandering and the Courts. New York, NY: Agathon, 178-202.

McDonald, Michael D. and Robin E. Best. 2015. "Unfair Partisan Gerrymandering in Politics and Law: A Diagnostic Applied to Six Cases." Election Law Journal 14: 312-30.

McDonald, Michael P. 2004. "A Comparative Analysis of Redistricting Institutions in the United States, 2001-02.” State Politics \& Policy Quarterly 4(4): 371-395.

McGann, Anthony J., Charles Anthony Smith, Michael Latner, and Alex Keena. 2016. Gerrymandering in America. New York: Cambridge University Press.

Miller, Peter and Bernard Grofman. 2013. "Redistricting Commissions in the Western United States. ”, UC Irvine Law Review, 3:637-62

Page v. Virginia State Board of Elections. 2014. 58 F.Supp. 3d 533 (E.D. Va).

Reynolds v. Sims. 1964.377 U.S. 533.

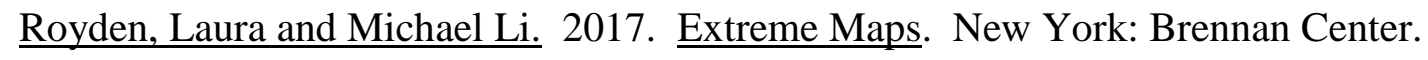

Rucho v. Common Cause. 2019. U.S. 
Snedecor, George W and William G Cochran. 1967. Statistical Methods. Ames, IA: Iowa State University Press.

Stephanopoulos, Nicholas and Eric McGhee. 2015. "Partisan Gerrymandering and the Efficiency Gap.” University of Chicago Law Review 82: 831-900.

Quitt, Martin H. 2008. “Congressional (Partisan) Constitutionalism: The Apportionment Debates of 1842 and 1844," Journal of the Early Republic 28: 627-51.

Wang, Samuel S.-H. 2016a. “A Three-prong Standard for Practical Evaluation of Partisan Gerrymandering." Stanford Law Review 68: 1263-1321.

Wang, Samuel S.-H. 2016b. "Three Practical Tests for Gerrymandering: Applications to Maryland and Wisconsin.” Election Law Journal 15:367-84.

Wang, Samuel S.-H., Brian A. Remlinger, and Ben Williams. 2018. An Antidote to Gobbledegook: Organizing the Judge's Partisan Gerrymandering Toolkit into Tests of Opportunity and Outcome.” Election Law Journal 17: 302-14.

Whitman v. Personhuballah. 2016. 136 S.Ct. 1732.

Wolf, Stephen. n.d. "DRA Update: 2012 President \& Downballot Election Results Estimates + Display Table Template.” Daily Kos. 4 August 2014. Accessed 24 July 2017. <http://www.dailykos.com/stories/2014/8/4/1318876/-DRA-Update2012-President-Downballot-Election-Results-Estimates-Display-Table-Template>. 